Birlesik Dünya Arastırma Cypriot Journal of Educational

\title{
The implementation of virtual choir recordings during distance learning
}

Hakki Cengiz Eren ${ }^{1}$, Near East University Ringgold standard institution - Department of Music Education, Karakum Önel Villa no: 12, Kyrenia 1403, Cyprus https://orcid.org/0000-0001-5331-8328

Emine Kıvanç Öztuğ ${ }^{\text {b }}$, Near East University Ringgold standard institution - music NEU, Nicosia 1403, Cyprus, https://orcid.org/0000-0002-1135-1418

\section{Suggested Citation:}

Eren, H. C., \& Öztuğ, E. K., (2020). The implementation of virtual choir recordings during distance learning. Cypriot Journal of Educational Science. 15(5), 1117-1127. https://doi.org/10.18844/cjes.v15i5.5159

Received from June 15, 2020; revised from August 15, 2020; accepted from October 25, 2020. C2020 Birlesik Dunya Yenilik Arastirma ve Yayincilik Merkezi. All rights reserved.

\begin{abstract}
This study investigates the implementation of virtual choir recordings in a choir class during distance learning. In this particular study, a virtual choir is defined to be a computer-generated sound recording that emulates a realistic choir sound. Students $(n=21)$ practiced their parts using virtual choir recordings for a period of eight weeks; each student received a recording that excluded his/her own part but included the rest of the parts. After eight weeks of progressive study, students recorded their own voices on top of the virtual choir recordings and submitted them as final projects. Student opinions regarding the virtual choir recordings were obtained through a 12-question survey. In addition, two experts evaluated the final submissions turned in by the students. The data suggests that virtual choir recordings can be helpful to students with efficiency of practice and can provide a suitable audio environment to foster conscious-listening, accurate intonation and perception of pacing. Improvements are suggested to make the virtual choir recordings also more encouraging of musicality, highlighting its future potential not only as a reliable distance education tool, but also as a supplementary device for real-life choir classes, when in-person learning resumes.
\end{abstract}

Keywords: music education, distance learning, choir, virtual choir, music technology

\footnotetext{
* ADDRESS FOR CORRESPONDENCE: Hakki Cengiz Eren, Near East University Ringgold standard institution Department of Music Education, Karakum Önel Villa no: 12, Kyrenia 1403, Cyprus

E-mail address: cengizhakki.eren@ neu.edu.tr / Tel.: +905338630802
} 


\section{Introduction}

Choir classes constitute an important part of music education. Various studies argue that singing together in a choir not only improves one's the ability to hear, listen to and to

read music, but also helps build socio-musical skills and collective responsibility. Robinson (1996) highlights the role of "singing together" on the development of aural skills, intonation, sight-reading and the aural-internalization of basic elements of music theory. Choir classes incorporate a variety of activities that can help students learn multiple skills. Dettwiler (1989) demonstrates how exercises that trigger internal hearing could be used to enhance aural capabilities of students during the warmup phases of a choir rehearsal. According to Demorest (1998), frequent individual testing during choir classes can play a potential role in improving musical reading. In working with children and teachers, Heyning (2010) describes how, during choir rehearsals, descriptive gestures and emotive words by teachers encouraged children to listen to the sounds around them more attentively. Choir classes provide students with an environment of diversified learning. Özçimen (2015) evaluated the opinions of 54 pre-service music teachers about a choir class they were attending. The survey results showed that, the most beneficial aspects of being in a choir for the participants were: thinking together, moving together, sharing, sense responsibility; finding the correct pitch and spreading it around, becoming a conscious listener; developing interpretation, musical sensibility, and acquiring the ability to sing together.

Choir practice is one of the most foundational, effective, and also widespread fields in music education. With respect to the principles of vocal education and the general objectives of a music program, choir education is shaped by concepts and activities such as practical exercises, solfege, harmony, interpretation, collective responsibility, choir culture and its stylistic features (Uçan, 2001). Choir classes are multidimensional environments in which students get to develop a variety of musical skills.

Following the Covid-19 pandemic, the Near East University Faculty of Music Education, like all other faculties within the institution, switched to distance learning in March 2020, as a precautionary measure. During the initial stages of the isolation period, handling the choir class has been particularly challenging for teachers; online platforms such as "Google Meet" or "Zoom" could not provide a realtime environment in which multiple people could sing together. To ensure that such an important class continued with minimum hindrance during distance learning, a supplementary tool was devised for students taking the choir course: the virtual choir. Literat (2012), attributes the term 'virtual choir' to the acclaimed modern composer Eric Whitacre, who collected 2,052 individual recordings of people singing the same music and combined the sound clips into a single collective entity. Schnell et al. (2000), on the other hand, define the term to be realistic choir sound that is more or less synthetic (computer-generated), without any usage of previously recorded real-life voices. In this case, the choir sound is generated synthetically using spectral information from a single voice. This study is congruent with the latter; virtual choir recordings were created using realistic-sounding virtual instruments; SATB (soprano, alto, tenor and bass) parts were generated one by one, using a virtual instrumentation program (Kontakt 5, version 10.13.6) and its sound library. The recordings were then subjected to various enhancements; dynamic shaping for each part was carried out in a digital audio workstation (Logic-Pro X, version 10.5.1) through volume automation. Ircam's Spat5 extension, a program that enables the user to spread out individual voices in a sonic field (left, right, front and back), was used to distribute each voice part within a 3-D stereo field and to enhance the sounds with reverberation. A metronome click accompanied the virtual recordings at all times for rhythmic support. The main objective was to provide students with a realistic choir environment, so that upon interacting with it regularly, they would continue to develop choir-related skills during distance education.

Virtual recordings of three pieces were created. Two of the pieces are first time arrangements of Turkish Cypriot songs composed by the group "SIla 4", while the third piece is a polyphonic 
arrangement of Seval Köse's one voice setting of a poem titled "Memleket İsterim" by Cahit Sıktı Tarancı. The pieces were chosen on the basis of diversity:

Ağaçlar Kalem Olsa, arranged by Hakkı Cengiz Eren

- Complex contrapuntal texture

- Complex harmonies

- Challenging rhythms

Göç, arranged by Hakkı Cengiz Eren

- Dialogue-like counterpoint with instruments

- Different combinations of choir parts (e.g. soprano-alto, tenor-bas)

- Complex harmonies

- Challenging rhythms

Memleket isterim, arranged by Hakkı Cengiz Eren

- Simple contrapuntal texture

- Tonal harmonies

- Simple rhythms

It should be noted that this study does not attempt to present a device that can ultimately replace a real-life choir class; the virtual choir cannot provide an incentive for the betterment of socio-musical abilities, nor can it induce, in the student, the sense of responsibility for a group. However, it is presumed that, using virtual choir recordings, students can still continue improving skills such as conscious-listening, harmonic awareness, musicality and sense of pacing, as they would in a real-life choir class.

\subsection{The Purpose of the Study}

The purpose of this study is to assess the usability of the virtual choir recording through student opinions and expert assessments of student performances, determine its shortcomings, and later, in the discussion section, suggest ways of improving it. Research questions include:

1. What do student questionnaire results tell about the suitability of virtual choir recordings for fostering (a) efficiency of practice (b) conscious-listening (c) harmonic awareness (d) musicality (e) sense of pacing in students?

2. Is there a statistically meaningful correlation between any of the elements in the questionnaire and expert assessments of student performances?

3. What are the shortcomings of virtual choir recordings with respect to the parameters of research question 1 ?

4. Based on findings from research question 3 , how can the virtual choir recordings be improved more to suit the needs of students?

\subsection{Assumptions}

A series of assumptions are put together regarding the usability of virtual choir recordings during distance education. It is expected that students will have efficient practice sessions with virtual choir sounds; with the opportunity to practice anytime, anywhere, they will have more time to enhance their skills compared to real-life rehearsals, which are limited in number. This way, they will be able to address their individual musical problems as many times as they wish. Virtual choir recordings used in this study constitute realistic sounds, distributed within a 3-D stereo field, with sophisticated reverberation. Thus, it is expected that virtual choir recordings will provide a suitable environment for students to listen consciously to other voices as well as their own. Moreover, the virtual choir recordings, being computer generated, are impeccable with respect to the accuracy of pitches, and so 
it is assumed they will provide a suitable audio environment for students to work on their intonations (a sub-category of musicality). A metronome sound is provided for each virtual recording, and this feature is expected to help students keep track of their timing in the absence of a conductor.

\subsection{Literature Review}

There have been various studies that incorporate some form of technology in choir classes, albeit very limited in number. Cremata (2010) investigated the use of technology in various music classes. During a semi-structured interview, a student $(\mathrm{HH})$ praised one particular teacher for making them compose music during choir classes using various multimedia software. $\mathrm{HH}$ says this particular activity helped them better understand and internalize the music they were singing

Petty and Henry (2014) tested the effects of voice recognition technology on the sight-reading abilities of beginning choir students. During an 8-week program with sixth grade students $(n=83)$ as participants, 47 students practiced sight-reading with SmartMusic software and headphones, while the remaining 36 students with only camera projection. Both groups were responsible for the same class material. No significant difference was found between the posttest results of the technology and the non-technology groups. Both groups improved at a similar rate.

Sever (2017) tested the usage of a computer, a projector and a sound system in choir classes. The subjects $(n=30)$ were students enrolled in a choir class at the Karabük University of Fine Arts. Pieces used in rehearsals were transferred into Sibelius (a music engraving program) and the notational progress was projected onto a screen while the sounds were played through a sound system. This way, the students benefited from both audio and visual support as they sang. A survey questionnaire revealed that students approved the use of technology insofar as how it contributed to their motivation, hearing and musical perception.

\section{Method}

The participants were 11 male and 10 female students $(n=21)$ enrolled in a choir class at the Near East University Faculty of Music Education, during 2019-2020 spring semester (distance learning period). Each student was provided with virtual choir recordings that excluded his/her own part but included the rest of the parts. In addition, slower versions of the same recordings were provided for more meticulous study. Students were also provided with single-voice versions, so that they could practice duets (e.g. soprano-alto, tenor-bass) before tackling 4-voice textures. Students were advised to study regularly with the virtual choir recordings for a period of eight weeks. The recommended way to practice was to sing along with the recordings using either headphones or a sound system. During the first 20 days, students practiced with single-voice versions (practicing duets), the next 20 days they practiced with slow three-part versions and the final 20 days with up-to-tempo three-part versions (the fourth part being their own voice). After each 20 day period, students, using a smartphone, recorded their own voices on top of the virtual choir recordings and uploaded them to the distance learning website, to be assessed by two experts, a choirmaster and choral conductor.

\subsection{Data Collection Tools}

After the eight-week period, students were asked to complete an online questionnaire. The questionnaire consisted of 11 closed-ended and one open-ended question. The closed-ended questions were categorized according to the parameters of research question 1: (a) efficiency of practice (b) conscious-listening (c) harmonic awareness (d) musicality (e) sense of pacing. Students could answer each question on a 3-point Likert scale (3- always 2- sometimes 1- never). The reason behind the implementation of a 3-point Likert scale, as opposed to a 5 point or more, was to be able to obtain as clear a data set as possible, without any 'gray areas' with respect to the responses. For the open-ended question, students were asked to write, in prose, the beneficial and inadequate aspects of practicing with virtual choir recordings. In addition to the questionnaire, the two aforementioned experts were given a scale to assess final student submissions. Using the scale, the 
experts evaluated each student over a grade of 1-5 with respect to accuracy of pitch, nuances, dynamics, articulations and rhythm for each of the three pieces.

\subsection{Data Analysis}

The questionnaire results have been analyzed through percentage and frequency distributions, as well as mean scores. The expert assessments of final student submissions have been grouped with respect to the three pieces used in the study. The mean scores for each category of assessment (accuracy of pitch, nuances, dynamics, articulations and rhythm), as well as the overall mean scores have been calculated. Finally, a Spearman Rank Correlation Test has been implemented to seek out correlations between student responses and overall expert assessments $(p<0,05)$.

\subsection{Reliability of Data}

The reliability of the questionnaire has been determined by the test-retest method. At the end of the 60 day period, the students received the questionnaire twice at 10 days interval. The overall Cronbach alpha value turned out to be 0.73 , demonstrating good internal consistency and therefore adequate reliability.

\section{Results}

In this section, questionnaire results are displayed in table format as frequency/percentage distributions and mean scores. In addition, the answers to the open-ended question are broken down by means of coding, and presented here in prose. The mean scores of expert assessments of student performances for each of the three pieces with respect to the aforementioned categories are given in table 6. Table 7 shows the correlations between student responses and overall mean scores of expert assessments $(p<0,05)$.

\subsection{Efficiency of Practice}

The students answered two questions regarding efficiency when practicing with virtual choir recordings, one regarding the regularity of study and the other regarding motivation.

Table 1. Student responses to questions about efficiency of study when practicing with virtual choir recordings $(n=21)$

\begin{tabular}{lllll}
\hline Question & Always & Sometimes & Never & Mean \\
& & & Score \\
\hline I practice regularly with virtual choir recordings & $12(57,1 \%)$ & $9(42,9 \%)$ & $0(0 \%)$ & 2,57 \\
I am motivated to practice with virtual choir & $9(42,9 \%)$ & $9(42,9 \%)$ & $3(14,3 \%)$ & 2,29 \\
recordings & & & \\
\hline
\end{tabular}

The majority of the students $(57,1 \%)$ reported that they "always" practiced regularly with the virtual choir recordings. In terms of being motivated, the number of students who answered "always" and "sometimes" are equally distributed (42,9\%), while a relatively small percentage of students $(14,3 \%)$ preferred to answer "never".

\subsubsection{Conscious Listening}

The students answered two questions regarding conscious-listening. These two questions sought to find out whether or not the students could clearly hear their own voices and the voices from the virtual choir simultaneously. The questions themselves do not refer to conscious listening because if the virtual choir is to foster conscious listening, the individual SATB parts in the recordings first need to be clearly audible for the student. 
Eren, H. C., \& Öztuğ, E. K., (2020). The implementation of virtual choir recordings during distance learning. Cypriot Journal of Educational Science. 15(5), 1117-1127. https://doi.org/10.18844/cjes.v15i5.5159

Table 2. Student responses to questions about conscious-listening when practicing with virtual choir recordings $(n=21)$

\begin{tabular}{lllll}
\hline Question & Always & Sometimes & Never & Mean \\
& & & Score \\
\hline I can hear my own voice & $7(33,3 \%)$ & $11(52,4 \%)$ & $3(14,3 \%)$ & 2,20 \\
$\begin{array}{l}\text { I can hear and distinguish the voices from the virtual } \\
\text { choir }\end{array}$ & $12(57,1 \%)$ & $9(42,9 \%)$ & $0(0 \%)$ & 2,57 \\
\end{tabular}

Evaluating the results from table 2, it can be deduced that the students could hear the voices from the virtual choir recordings ( $57,1 \%$ reported as always) more clearly than their own voices (only $33,3 \%$ reported as always). $14,3 \%$ of students reported "never" being able to hear their own voices, whereas no student reported "never" being able to hear the other voices.

\subsubsection{Harmonic Awareness}

The students answered three questions regarding harmonic awareness. These questions sought to find out if the students could clearly hear the intervals, chords and the function of their own voices with respect to voice leading when practicing with virtual choir sounds.

Table 3. Student responses to questions about harmonic awareness when practicing with virtual choir recordings $(\mathrm{n}=21)$

\begin{tabular}{lllll}
\hline Question & Always & Sometimes & Never & Mean \\
& & & Score \\
\hline I can hear the intervals & $5(23,8 \%)$ & $13(61,9 \%)$ & $3(14,3 \%)$ & 2,10 \\
I can hear the chords & $7(33,3 \%)$ & $14(66,7 \%)$ & $0(0 \%)$ & 2,33 \\
I am aware of the voice leading & $9(42,9 \%)$ & $9(42,9 \%)$ & $3(14,3 \%)$ & 2,29 \\
\hline
\end{tabular}

Upon evaluating the results from table 3, it can be deduced that a larger portion of students preferred to answer "sometimes" or "never" for questions regarding harmonic awareness (76,2\% for intervals, $66,7 \%$ for chords and $57,2 \%$ for voice leading). 14,3\% of students reported "never" being able to hear intervals and the voice leading. No student reported "never" being able to hear the chords.

\subsubsection{Musicality}

The students answered four questions regarding musicality. These questions sought to find out if the students were able to control the intonation of their own voices when practicing with virtual choir sounds, and if the recordings provided enough incentive for them to execute nuances, dynamics and articulations. Here it might seem like intonation would be a separate topic, but as Cuesta et al. (2018) mention, intonation not only implies pitch accuracy, but also slight deviations from the 'correct pitch': the vibrato component. Drieger et al. (2016) note that musicians frequently resort to the usage of vibrato for expressive purposes. 
Eren, H. C., \& Öztuğ, E. K., (2020). The implementation of virtual choir recordings during distance learning. Cypriot Journal of Educational Science. 15(5), 1117-1127. https://doi.org/10.18844/cjes.v15i5.5159

Table 4. Student responses to questions about musicality when practicing with virtual choir recordings $(n=21)$

\begin{tabular}{lllll}
\hline Question & Always & Sometimes & Never & $\begin{array}{c}\text { Mean } \\
\text { Score }\end{array}$ \\
\hline I am able to control the intonation of my voice & $14(66,7 \%)$ & $6(28,6 \%)$ & $1(4,7 \%)$ & 2,62 \\
I am encouraged to execute nuances & $10(47,6 \%)$ & $8(38,1 \%)$ & $3(14,3 \%)$ & 2,33 \\
I am encouraged to execute dynamic gestures & $9(42,9 \%)$ & $10(47,6 \%)$ & $2(9,5 \%)$ & 2,33 \\
I am encouraged to execute the indicated & $8(38,1 \%)$ & $12(57,1 \%)$ & $1(4,8 \%)$ & 2,33 \\
articulations & & & & \\
\hline
\end{tabular}

The results from table 4 reveal that a larger portion of students $(66,7 \%)$ reported they could "always" control the intonation of their voices. Only one student $(4,7 \%)$ reported "never" being able to control the intonation of his/her voice. As for nuances, dynamics and articulations, a larger portion of students reported "sometimes" or "never" being encouraged to execute them (52,4\% for nuances, $57,1 \%$ for dynamics and $61,9 \%$ for articulations). A relatively small percentage of students reported "never" being encouraged to execute nuances, dynamics and articulations ( $14,3 \%$ for nuances, $9,5 \%$ for dynamics and $4,8 \%$ for articulations).

\subsubsection{Pacing}

The students were asked one question regarding pacing. This question sought to find out if the students were able to execute correct rhythms, thereby being able to keep track of their timing in the absence of a conductor.

Table 5. Student responses to the question about pacing when practicing with virtual choir recordings $(n=21)$

\begin{tabular}{lllll}
\hline Question & Always & Sometimes & Never & Mean \\
& & & Score \\
\hline $\begin{array}{l}\text { I am able to execute correct rhythms without losing } \\
\text { track of my timing }\end{array}$ & $14(66,7 \%)$ & $6(28,6 \%)$ & $1(4,8 \%)$ & 2,62 \\
\hline
\end{tabular}

The data from table 5 shows that a larger portion of students $(66,7 \%)$ reported they were "always" able to execute the correct rhythms without losing track of their timing. Only one student $(4,8 \%)$ preferred to answer "never" in this case.

\subsubsection{Student Responses to the Open-ended Question}

Of the 21 students participating in this study, 17 students answered the open-ended question regarding the beneficial and inadequate aspects of practicing with virtual choir recordings. 5 students mentioned that practicing with virtual choir sounds was an efficient way to study for the choir class. 6 students were of the opinion that they could control their intonation better with virtual choir recordings than they could in a real-life rehearsal. 4 students mentioned that there was not enough incentive for them to be musical with respect to gestures and nuances. No students touched upon the subject of harmonic awareness.

Below are the expert assessments of the students' final submissions with respect to accuracy of pitch, nuances, dynamics, articulations and rhythm. The final submissions, as mentioned before, contain the student's recorded voice as he/she sings on top of the virtual recordings. For each of the categories below, the students were graded over a maximum grade of 5 . The Mean scores and the medians of each category were calculated separately for each of the three pieces used in this study. 
Eren, H. C., \& Öztuğ, E. K., (2020). The implementation of virtual choir recordings during distance learning. Cypriot Journal of Educational Science. 15(5), 1117-1127. https://doi.org/10.18844/cjes.v15i5.5159

\subsection{Expert Assessments Of Students' Final Submissions and Correlations Between Student Responses and Overall scores}

Table 6. Expert assessments of student final projects $(\mathrm{n}=21)$

\begin{tabular}{lllllllll}
\hline & $\begin{array}{l}\text { Ağaçlar Kalem } \\
\text { Olsa }\end{array}$ & & $\begin{array}{l}\text { Memleket } \\
\text { isterim }\end{array}$ & & Göç & \multicolumn{3}{c}{ Overall } \\
& $\begin{array}{l}\text { Mean } \\
\text { Score }\end{array}$ & Median & $\begin{array}{l}\text { Mean } \\
\text { Score }\end{array}$ & Median & $\begin{array}{l}\text { Mean } \\
\text { Score }\end{array}$ & Median & $\begin{array}{l}\text { Mean } \\
\text { Score }\end{array}$ & Median \\
\hline $\begin{array}{l}\text { Accuracy } \\
\text { pitch }\end{array}$ & 3,62 & 4 & 4,1 & 4 & 3,76 & 4 & 3,82 & 3,67 \\
Nuances & 2,38 & 2 & 2,57 & 2 & 2,86 & 2 & 2,60 & 2,33 \\
Dynamics & 2,61 & 2 & 2,67 & 2 & 2,71 & 3 & 2,67 & 2,67 \\
Articulations & 2,38 & 2 & 2,67 & 2 & 2,52 & 3 & 2,52 & 2,66 \\
Rhythm & 3,96 & 4 & 4,43 & 4 & 4,2 & 5 & 4,19 & 4,00 \\
\hline
\end{tabular}

The mean scores for pitch accuracy and rhythm turned out to be the highest for each of the three pieces, whereas the mean scores for nuances, dynamics and articulations are lower in comparison. Conscious listening and harmonic awareness were not incorporated into the assessment sheet, because the scope of this particular study allows only the students to testify for their perceptual presence. The mean scores for Ağaçlar Kalem Olsa, the most challenging piece, are the lowest, whereas Memleket Isterim and Göç, being relatively less challenging, received higher mean scores.

Table 7. The correlations between overall expert assessments and student responses $(n=21)$

\begin{tabular}{|c|c|c|}
\hline & & $\begin{array}{l}\text { Overall expert } \\
\text { assessments }\end{array}$ \\
\hline \multirow{2}{*}{ Efficiency of Practice } & $r$ & 0,312 \\
\hline & $\mathrm{p}$ & 0,169 \\
\hline \multirow{2}{*}{ Conscious Listening } & r & 0,392 \\
\hline & $\mathrm{p}$ & 0,078 \\
\hline \multirow{2}{*}{ Harmonic Awareness } & r & 0,583 \\
\hline & $p$ & $0,006^{*}$ \\
\hline \multirow{2}{*}{ Musicality } & r & 0,475 \\
\hline & $p$ & $0,030^{*}$ \\
\hline \multirow{2}{*}{ Pacing } & r & 0,262 \\
\hline & $\mathrm{p}$ & 0,252 \\
\hline
\end{tabular}

${ }^{*} p<0,05$ (r: Spearman test)

Observing Table 7, it is seen that there is statistically significant and positive correlation between overall expert assessments and students' harmonic awareness and musicality responses $(p<0,05)$. This means that as the students' harmonic awareness and musicality responses increase, overall expert assessments scores also increase. No statistically significant correlation has been observed between 
overall expert assessments and students' efficiency of practice, conscious listening and pacing responses.

\section{Discussion and Conclusion}

A specific attribute of the virtual choir used in this study is said to be sufficient, and therefore suitable for the needs of the students, if the majority of the responses for the corresponding element of the questionnaire lie in the "always" range, with no more than $\% 5$ accounting for the "never" range. These include regularity of practice (the first element of (a) efficiency of practice); the ability to distinguish specific voices from the virtual choir (the second element of (b) conscious listening); intonation (the first element of (d) musicality) and (e) pacing. A specific attribute of the virtual choir is said to be insufficient, and therefore not suitable for the needs of students, if the majority of the responses for the corresponding element of the questionnaire lie in the "sometimes" and "never" range. These include motivation (the second element of (a) efficiency of practice); the ability to hear his/her voice (the first element of (b) conscious listening); all elements of (c) harmonic awareness and all elements of (d) musicality, excluding intonation. The responses to the open-ended question reveal that students had easier time with issues like pitch accuracy and efficiency as opposed to musicality.

Expert assessments of the final student submissions show higher mean scores for intonation and pacing/rhythm than those of musicality. In general, these results agree with student opinions; students reported being able to handle pitch and rhythm better than parameters of musicality. The overall mean scores are also congruent with this conclusion. As mentioned before, elements of conscious listening and harmonic awareness were not incorporated into the expert assessments; nevertheless, pitch accuracy results could be an indication that students listened consciously, and to a degree, with somewhat adequate harmonic awareness. The Spearman Rank Correlation Test shows statistically significant correlations between student responses for harmonic awareness/musicality and overall expert scores. This means that the lower the overall grade a student received, the lower his/her Likert scale selection with respect to harmonic awareness and musicality. This can have the implication that lower grades are more associated with lower levels of harmonic awareness and musicality than any of the other categories. These implications are indicative of the shortcomings of the virtual choir, namely that the particular recordings used in this study might not entirely be suitable to foster harmonic awareness and musicality in students. These issues are to be dealt with in the following paragraphs.

But firstly, one particular issue belonging to the category of conscious listening needs to be addressed. The majority of the students reported either "sometimes" or "never" being able to hear their own voices when practicing with virtual choir recordings. This issue might arise from the discrepancy of acoustic space between the student's voice and the virtual voices; the student sings into his/her surroundings, whereas the virtual voices come out of the headphones. A new recommended way of practicing could incorporate a microphone, which could be used to redirect the student's voice into the computer and out from the headphones, bringing the student's voice and the virtual voices into the same acoustic space.

The data in this study shows that majority of students were only "sometimes" or "never" aware of aspects of harmony (intervals, chords and voice leading). Perhaps the culprit here is not necessarily the virtual choir recordings or choir classes themselves, but rather long-term inefficiencies in theory and ear-training classes. Music education programs, the majority of which still implement rather conservative methods of teaching, could incorporate more technological tools to induce harmonic awareness in students. Molumby (2014) asserts that mobile technology (iPAD in this case) has a big potential for use in classes designated for training ears. He suggests "Ear Trainer", whose many features include: interval comparison; interval identification; chord identification; chord progressions; scales, etc. Molumby also recommends "Virtuoso Piano Free3"; he claims that with this application, a student can indulge in a series of exercises designated for ear-training classes, practice for class anytime, anywhere, and check his/her homework before turning it in. Chen (2015) found out that 
Auralbook, an application that enables students to sing, clap, record and answer computer generated questions, contributed to aural skill levels of students associated with ABRSM (grades 1-8). As useful as they might be in training ears to a degree, many of these applications come with unsophisticated and non-realistic sounds, with few instrument choices (mostly a piano sound). Applications like these should be developed further to include more realistic sounds, with more virtual instrument choices. The more the students enhance skills related to harmony in such classes, the more awareness they would attain with respect to harmony, and technology, as mentioned, can have a large impact.

One other shortcoming of the virtual choir has been its unsuitableness for encouraging musicality; student evaluations and expert assessments confirm this. The sound samples used in this recording were realistic to a degree, but lacked expressivity and naturalness. When a singer uses a particular gesture, the sound undergoes timbral variations; but the "imitation-expressivity" in the virtual choir recordings does not incorporate these timbral variations (e.g. volume automation for dynamics). Thus, the resultant sounds were not convincing in terms of musicality. According to Bonada and Blaauw (2020), the main parameters controlling the naturalness and expressivity of a singing voice are the fundamental frequency (F0) "trajectories" (sound qualities that result from manipulation of singing gestures centered around F0). Taking advantage of recent advances in Deep Neural Network (DNN), they have proposed a model that can accurately extract and internalize parameters of complex F0 trajectories from a real recording and thereby produce highly realistic virtual choir sounds with expressive qualities. In their research, Schnell et al. (2000) sought to generate realistic choir sounds by implementing a technique called "Pitch Synchronous Overlap Add (PSOLA)". With this technique, they were able to generate a highly realistic choir sound with a wide range of timbers and textures. Research should be undertaken to make such advances in virtual sound generation more compatible with technological tools used in music classes, considering that most such tools for training musicians are unmusical, with dull and uninspiring sounds. Virtual choir sounds used in this study could also benefit from these. It can be presumed that making the virtual choir more musicality-inducing might also increase the motivation levels of the students when practicing.

This study initially aimed to test the usability of virtual choir recordings during distance learning. As the virtual recordings were being built and certain hypotheses structured, it became clear that these recordings could potentially be a perpetual part of choir classes as an auxiliary tool, even after inperson learning fully resumes. Initial predictions and the data obtained suggest that virtual choir recordings can be helpful to students with efficiency of practice, and that they can provide a suitable audio environment to foster conscious-listening, intonation, and perception of pacing in students. While it might seem like virtual choir recordings are not ideal for students to enhance their harmonic awareness, this issue, as mentioned above, needs to be addressed within a more general framework that also includes theory and sight-singing courses. What might help overcome this issue in the long run is the inclusion of ever-advancing technological tools in more areas of music education, such as aural skills or music theory classes. Virtual choir recordings used in this study did not turn out to be ideal for encouraging students to be more musical; while the artificial sounds were realistic to a degree, they lacked the timbral and textural variety of an actual choir sound. If a more "musicallyconvincing" virtual choir recording is to be created, new techniques in virtual sound generation, like the ones mentioned above, should be incorporated into its making. With these improvements, the virtual choir can become not only a reliable tool during distance education, but also powerful supplementary tool for choir classes when in person learning resumes. Further research should incorporate a larger sample of subjects and more advanced technology.

\section{References}

OZCIMEN, A. (2015). Pre-service music teachers opinions about the significance of choir lesson. Educational Research and Reviews, 10(7), 879-886. https://doi.org/10.5897/ERR2015.2090

Bonada, J., \& Blaauw, M. (2020, May). Hybrid Neural-Parametric F0 Model for Singing Synthesis. In ICASSP 20202020 IEEE International Conference on Acoustics, Speech and Signal Processing (ICASSP) (pp. 72447248). IEEE. DOI: 10.1109/ICASSP40776.2020.9054707 
Eren, H. C., \& Öztuğ, E. K., (2020). The implementation of virtual choir recordings during distance learning. Cypriot Journal of Educational Science. 15(5), 1117-1127. https://doi.org/10.18844/cjes.v15i5.5159

Chen, C. W. J. (2015). Mobile learning: Using application Auralbook to learn aural skills. International journal of music education, 33(2), 244-259. https://doi.org/10.1177/0255761414533308

Cremata, R. (2010). The use of music technology across the curriculum in music education settings: Case studies of two universities. Boston University. Retrieved from https://search.proquest.com/openview/920deff75576940ccdb8309b7412a66d/1?pqorigsite $=$ gscholar $\& \mathrm{cbl}=18750 \&$ diss $=\mathrm{y}(\mathrm{PhD}$ dissertation available on Proquest)

Cuesta, H., Gómez Gutiérrez, E., Martorell Domínguez, A., \& Loáiciga, F. (2018). Analysis of intonation in unison choir singing. Retrieved from https://repositori.upf.edu/handle/10230/35953

Demorest, S. M. (1998). Improving sight-singing performance in the choral ensemble: The effect of individual testing. Journal of Research in Music Education, 46(2), 182-192. https://doi.org/10.2307/3345622

Dettwiler, P. (1989). Developing aural skills through vocal warm-ups: Historical overview of pedagogical approaches and applications for choral directors. Choral Journal, 30(3), 13. Retrieved from https://search.proquest.com/openview/3949faab2e82544b5ada29ae97127ecd/1?pqorigsite $=$ gscholar $\& \mathrm{cbl}=1821226$

Driedger, J., Balke, S., Ewert, S., \& Müller, M. (2016). Template-based vibrato analysis in music signals.

Heyning, L. (2010). The enhancement of musical and other learning for both teachers and students through a weekly choir session. Australian Journal of Music Education, (1), 58. https://search.informit.com.au/documentSummary;dn=691265582321982;res=IELHSS

Literat, I. (2012). The work of art in the age of mediated participation: Crowdsourced art and collective creativity. International Journal of Communication, 6, 23.

Molumby, N. L. (2014, January). An iPad Masterclass: Mobile Technology in a University Aural Skills Class. In College Music Symposium (Vol. 54). The College Music Society. Retrieved from

https://www.jstor.org/stable/26574362?casa token=hH4LtGuF1MUAAAAA\%3Aq49xTUM rD9 z04-

¡hyJxmVE

AJnsAVMBIRKGOcXMCmXgmrEwU0KyiYnmYbOdF6beGPpnsXyZ5zJ7Fq4guAKdKVRGfFJ9KpIIWme1jWU hQ3ZOXzIw4\&seq=1\#metadata_info_tab_contents

Petty, C., \& Henry, M. L. (2014). The Effects of Technology on the Sight-Reading Achievement of Beginning Choir Students. Texas Music Education Research, 23, 28. https://eric.ed.gov/?id=EJ1102254

Robinson, M. (1996). To Sing or Not to Sing in Instrumental Class: Introducing vocalization techniques at the beginning of band or orchestra rehearsals can improve musical and critical-thinking skills of young performers. Music Educators Journal, 83(1), 17-47. https://doi.org/10.2307/3398989

Schnell, N., Peeters, G., Lemouton, S., Manoury, P., \& Rodet, X. (2000). Synthesizing a choir in real-time using Pitch Synchronous Overlap Add (PSOLA). In ICMC. Retrieved from http://articles.ircam.fr/textes/Schnell00a/index.pdf

Sever, S. (2012). TEKNOLOJI DESTEKLI KORO DERSI UYGULAMASI [Technological Implementations in a Choir Course]. Sanat Dergisi, (21), 85-96. Retrieved from https://dergipark.org.tr/en/pub/ataunigsfd/issue/2609/33578

Uçan, A. (2001). İnsan, Müzik ve Koro Eğitiminin Temelleri, I. [The educational foundations of the Individual, Music and Choir Education]. In National Ankara Symposium, Gazi University Gazi Education Faculty, Ankara. 